\title{
Patent foramen ovale and paradoxical coronary artery embolism: rare event with great clinical relevance
}

\author{
Claudia Morabito ${ }^{a}$ Michele Scarano ${ }^{b}$, Eugenio Genovesib ${ }^{\text {, Vittoria Vaccaro }}$, \\ Giulia Laterraa, Pasquale Crea ${ }^{a}$, Giuseppe Dattiloa, Matteo Casale ${ }^{a}$ \\ a Department of Clinical and Experimental Medicine, University of Messina, Italy \\ 'Cardiology Unit, Emergency Department, Hospital "Madonna del Soccorso", San Benedetto del Tronto, Italy
}

\section{ARTICLE INFO}

Article history:

Submitted: 23. 7. 2019

Revised: 1. 11. 2019

Accepted: 5. 12. 2019

Available online: 7. 7. 2020

Klíčová slova:

Infarkt myokardu s elevacemi úseku ST

Ischemická choroba srdeční

Otevřené foramen ovale

Paradoxní embolie koronární tepny

\section{SOUHRN}

Otevřené foramen ovale (PFO) je nejčastější strukturální srdeční anomálií spojenou s paradoxní embolíí. Onemocnění zvyšující tlak v dutinách pravého srdce, např. plicní embolie, mohou zpưsobit otevření PFO a zvýšit riziko průchodu trombů ze žilního do tepenného oběhu. Paradoxní embolie je vzácnou príhodou se závažnou prognózou. Tato kazuistika popisuje př́pad 77leté ženy, která byla dopravena na oddělení akutního příjmu pro dyspnoe, zmatenost a bolest na hrudi s kardiogenním šokem. EKG prokázalo významnou elevaci úseku ST ve vysokých laterálních svodech. Jak EKG, tak klinické vyšetření naznačovalo masivní plicní embolii s následnou paradoxní embolií přes PFO, což vedlo k akutnímu infarktu myokardu. Okamžitě byla zahájena trombolytická terapie; infuzi komplikovala bezpulsová elektrická aktivita vedoucí k úmrtí přes odpovídající rozšiřenou podporu životních funkcí. Kazuistika upozorňuje na význam rozpoznání a pečlivého zhodnocení známek a příznaků paradoxní a periferní embolie na podkladě plicní embolie u pacientů s PFO.

(c) 2020, ČKS.
Keywords:

Coronary artery disease

Paradoxical coronary artery embolism

Patent foramen ovale

ST elevation myocardial infarction

\begin{abstract}
Patent foramen ovale (PFO) is the most common structural cardiac anomaly associated with paradoxical embolism. Conditions increasing right heart chambers pressure, such as pulmonary embolism, can lead to its opening with increased risk of passage of thrombi from the venous to arterial circulation. Paradoxical embolism is a rare event with a possible severe prognosis. This case report is focused on a 77-year-old woman who was transported to the Emergency Department because of dyspnea, confusion, and chest pain with cardiogenic shock. The ECG showed a significant ST-T elevation in the high lateral leads. Both echocardiographic and clinical data suggested massive pulmonary embolism and consequent paradoxical embolism through a PFO, causing acute myocardial infarction. Immediate fibrinolytic therapy was performed; infusion was complicated by pulseless electrical activity leading to death despite adequate advanced life support. The report discusses the importance of carefully evaluating and recognizing the signs and symptoms of paradoxical coronary and peripheral embolism, secondary to pulmonary embolism, in patients with PFO.
\end{abstract}

Address: Prof. Giuseppe Dattilo, Department of Clinical and Experimental Medicine, Section of Cardiology, AOU "Policlinico G. Martino", Via Consolare Valeria n.1, 98125 Messina, Italy, e-mail: giu.dattilo@libero.it DOI: $10.33678 /$ cor.2019.083 


\section{Introduction}

Patent foramen ovale (PFO) is defined as the persistence of a patency between the septum primum and the septum secundum located in the oval pit. The PFO is the path needed for the physiological blood flow from right atrium to atrium during prenatal life. After the delivery the increase of left atrial pressures of the newborn, consequent to the activation of pulmonary circulation, results in a functional closure of this patency with later anatomical closure. Some studies showed a persistent patency of foramen ovale in $25-35 \%$ of the adult population. ${ }^{1-3}$ It is therefore a very common congenital abnormality in the general population, in most cases asymptomatic. Sometimes the closure is on a functional basis with a valve mechanism leading to its opening only with increase in right heart chambers pressure. Therefore pathological conditions increasing right heart chambers pressure, such as pulmonary hypertension, pulmonary embolism and even Valsalva maneuver, may facilitate its opening leading to paradoxical embolism because of passage of thrombi or emboli from the venous to the arterial circulation through a right-left shunt, as described by Cohnheim. ${ }^{4}$ Several cases of transient thrombi through a PFO and subsequent peripheral embolization have been reported in literature. ${ }^{5-12}$

\section{Case presentation}

A 77-year-old woman was transported to Emergency Department because of cardiogenic shock with dyspnea, retrosternal chest pain for about an hour and confusion. She had a history of psoriasis, arterial hypertension, and mild hypercholesterolemia with sporadic episodes of atypical chest pain. A previous stress echocardiography by dipyridamole of few months before was normal. ${ }^{13,14}$ In the Emergency Department the patient was cold and

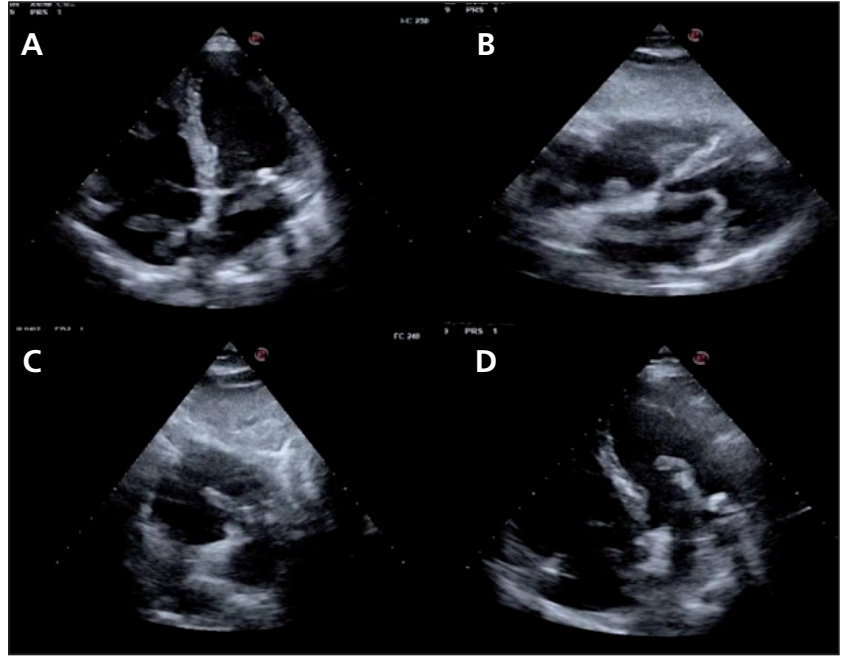

Fig. 2 - (A) Four-chamber apical view with evidence of thrombotic formation in the right atrium attached to the SIA and in the left atrium. (B) Four-chamber subcostal view: thrombotic formation prolapsing in the left ventricle through the SIA and through the mitral valve. (C) Subcostal view: Probable passage of thrombotic formation through SIA. (D) Four-chamber apical view: thrombotic formation prolapsing in the left ventricle.

sweaty with clinical signs of cardiogenic shock (blood pressure [BP] 70/40 $\mathrm{mmHg}$, heart rate [HR] 110/min). The ECG showed a significant ST-T elevation in the high lateral leads (Fig. 1). An echocardiogram showed several echogenic formations moving from the right to the left atrium in some case prolapsing in the respective ventricles during diastole with obvious passage through the interatrial septum (Fig. 2). On the aortic valve, a similar formation was attached to the non-coronary cusp (Fig. 3A). 5,6 Ventricles were both dilated and hypokinetic (ejection fraction [EF] $30 \%$, tricuspid annular plane systolic excursion [TAPSE] $11 \mathrm{~mm}$ ), with overt signs of pressure overload in right chambers (D-shape left ventricle, McConnell's sign) and

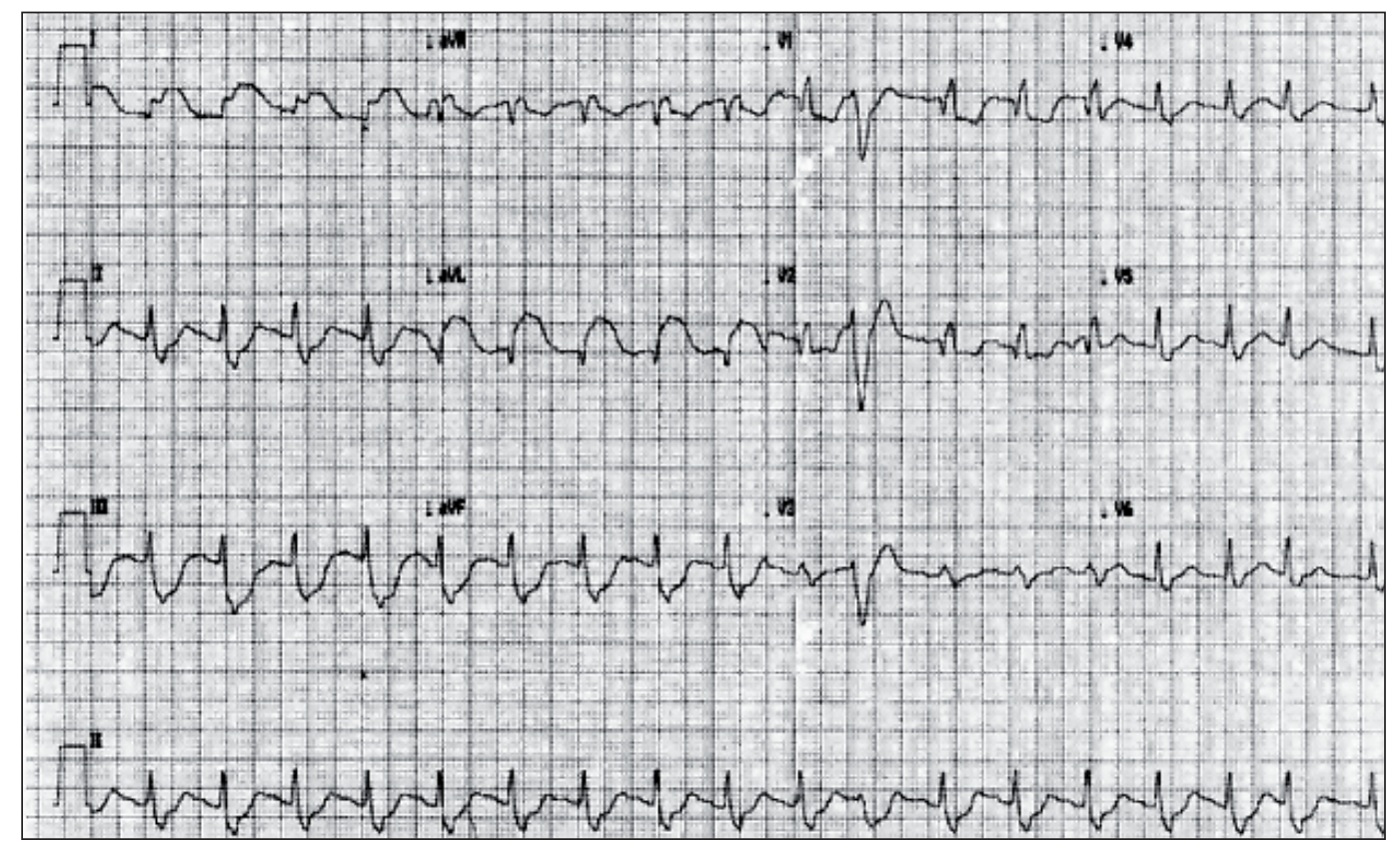

Fig. 1 - ECG: ST

elevation in I and aVL. 


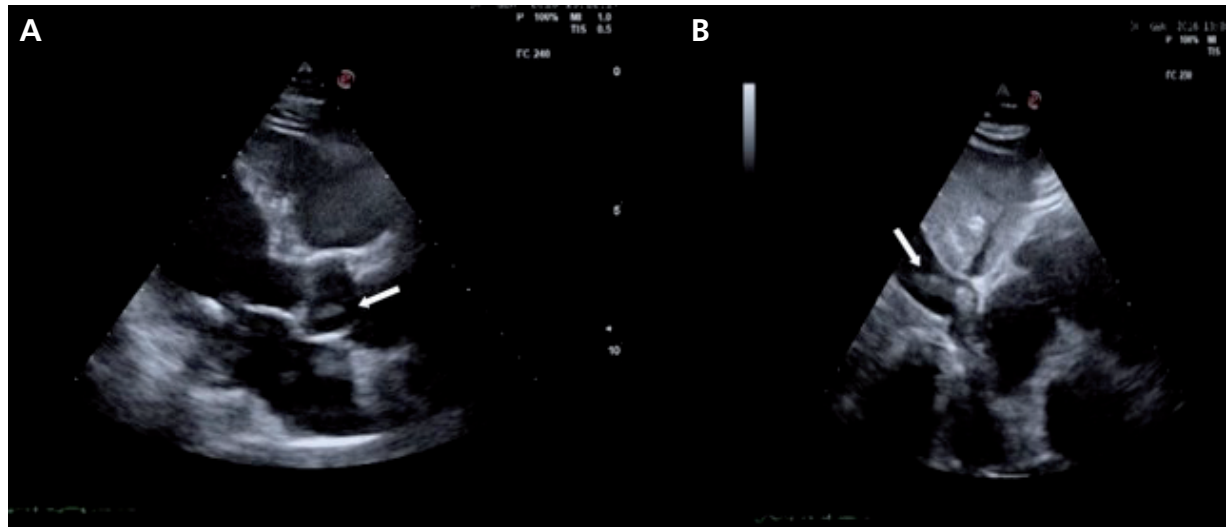

Fig. 3 - (A) Parasternal long axis view with evidence of formation adhering to the aortic cusp (arrow). (B) Subcostal view with evidence of filamentous formation, mobile in vena cava (arrow).

pulmonary hypertension (systolic pulmonary artery pressure [sPAP] $52 \mathrm{mmHg}$ ); in addition a low flow in the inferior vena cava vein with a pre-thrombotic state (sludge) was observed (Fig. 3B). Blood tests showed high troponin values (445 pg/ml), D-dimer $>40 \mu \mathrm{g} / \mathrm{ml}$, C-reactive protein (CRP) $15.39 \mathrm{mg} / \mathrm{dl}$, and normal procalcitonin. This clinical scenario was compatible with massive pulmonary embolism and consequent paradoxical embolism through the PFO. ${ }^{15,16}$ Immediate fibrinolytic therapy with an alteplase bolus was started. During the infusion the clinical status was complicated by a pulseless electrical activity leading to death despite advanced life support.

\section{Discussion}

As suggested by literature patent foramen ovale is the most common cardiac structural anomaly associated with paradoxical embolism. ${ }^{17}$ This case demonstrates the dynamic nature of PFO because, even if functionally closed, a significant pressure overload in right chambers makes its reopening a possible eventuality, with a consequent right to left shunt and coronary and peripheral paradoxical embolism. Although it is a relatively rare event ( $2 \%$ of systemic arterial embolism), it can lead to possible severe prognosis, with a mortality rate of $21 \% .{ }^{17}$

The purpose of this case report is to emphasize the importance of a careful screening for PFO even in asymptomatic patients and in those ones with an overt diagnosis a prompt advanced screening could be of prognostic importance. In fact patients with a patent foramen ovale $>4 \mathrm{~mm}$ with concomitant pulmonary embolism have a 5-fold higher risk of developing systemic embolism and a 10-fold higher risk to experience death than patients without patent foramen ovale. ${ }^{18}$

The most common clinical manifestation of paradoxical embolism is stroke; ${ }^{19}$ less frequent is the occurrence of upper limb embolism, kidney ischemia, retinal artery occlusion. The occurrence of acute myocardial infarction with ST elevation is a rare event, as in our case. Paradoxical coronary embolization should be suspected in patients with chest pain and low cardiovascular risk profile. ${ }^{20}$ Echocardiography is crucial for diagnosis, allowing preventive study of the interatrial septum with attention to the relationship between septum primum and secun- dum, and to measure the amplitude of patency and the degree of left-to-right shunt (especially by transesophageal echocardiography). ${ }^{21}$ This case demonstrates that a high level of suspicion should be maintained in these patients, performing a venous Doppler of the lower limbs as a screening for early detection of thrombosis, especially those ones with thrombophilia. ${ }^{22}$ Exclusion of cardiac sources of embolism has particular importance in PFO patients with implanted cardiac devices. ${ }^{23}$ A careful screening and, were appropriate, a prompt antithrombotic therapy ${ }^{24}$ could be life-saving in some PFO patients, where a direct visualization of emboli crossing the foramen ovale could be too late.

\section{Conflict of interest}

None.

\section{Funding body}

None.

\section{Ethical statement}

Authors state that the research was conducted according to ethical standard.

\section{References}

1. Lynch JJ, Schuchard GH, Gross CM, et al. Prevalence of right-to-left atrial shunting in a healthy population: detection by Valsalva maneuver contrast echocardiography. Am J Cardiol 1984;53:1478-1480.

2. Chen WJ, Kuan P, Lien WP, et al. Detection of patent foramen ovale by contrast transesophageal echocardiography. Chest 1992;101:1515-1520.

3. Jones HR Jr, Caplan LR, Come PC, et al. Cerebral emboli of paradoxical origin. Ann Neurol 1983;13:314-319.

4. Cohnheim J. Thrombose und Embolie: Vorlesungüber allgemeine Pathologie. Berlin: Hirschwald, 1877:134.

5. Chan FP, Jones TR. Images in clinical medicine. Paradoxical embolus. N Engl J Med 2001;345:803.

6. Dörr M, Hummel A. Images in clinical medicine. Paradoxical embolism - thrombus in a patent foramen ovale. N Engl J Med 2007;357:2285

7. Reid LE, Dawson DK. Paradoxical embolism via an atrial septal defect: in flagrante delicto. J Am Coll Cardiol 2010;56:e43.

8. Pávková $L$, Jelínek $P$, Pešl $L$, et al. Coincidence of deep venous thrombosis, pulmonary embolism and multiple paradoxical embolisms in a patient with patent foramen ovale. Cor Vasa 2011;53:654-657. 
9. Rácz B, Linhart A, Bělohlávek J, et al. Rare cause of recurrent systemic embolism in a middle-aged woman with undiagnosed lung A-V malformation. Cor Vasa 2019;61:e85-e89.

10. Hutyra M, Vindiš D, Šaňák D, et al. Acute pulmonary embolism and patent foramen ovale - neglected risk association. Cor Vasa 2011;53:348-352.

11. Honěk T, Veselka J, Tomek A, et al. Patent foramen ovale as a cause of paradoxical embolism in scuba divers. Cor Vasa 2006;48:286-288.

12. Neupane S, Kommuri NVA, Hauser AM. Caught in the middle: Thrombus-in-transit through patent foramen ovale. Cor Vasa 2015;57:e59-e60.

13. Dattilo G, Imbalzano G, Casale M, et al. Psoriasis and Cardiovascular Risk: Correlation Between Psoriasis and Cardiovascular Functional Indices. Angiology 2018;69:31-37.

14. Dattilo G, Imbalzano $E$, Lamari A, et al. Ischemic heart disease and early diagnosis. Study on the predictive value of 2D strain. Int J Cardiol 2016;215:150-156.

15. Imbalzano E, Saitta A, Lamari A, et al. Echo-Doppler evaluation of recent onset chronic venous insufficiency in elderly patients: does the heart have a role? Recenti Prog Med 2013;104:569573.

16. Imbalzano E, Di bella G, Lamari A et al. Right ventricular myocardial deformation in young healthy subjects: A comparison study between 2D strain and traditional parameters. J Exp Clin Cardiol 2014;20:2729-2743.
17. Caretta G, Robba D, Bonadei I, et al. Multiorgan paradoxical embolism consequent to acute thromboembolism with patent foramen ovale: a case report. Cases J 2009;2:8358.

18. Kessel-Shaefer A, Lefkovits M, Zellwegwe MJ, et al. Migrating thrombus trapped in a patent foramen ovale. Circulation 2001;103:1928.

19. Zito C, Dattilo G, Oreto G, et al. Patent foramen ovale: comparison among diagnostic strategies in cryptogenic stroke and migraine. Echocardiography 2009;26:495-503.

20. Hakim FA, Kransdorf EP, Abudiab MM, et al. Paradoxical coronary artery embolism - A rare cause of myocardial infarction. Heart Views 2014;15:124-126.

21. Maffè $S$, Dellavesa $P$, Perruca $A$, et al. Pulmonary embolism associated with paradoxical arterial embolism in a patient with patent foramen ovale. G Ital Cardiol 2008;9:637-640.

22. Scarano M, Casale M, Mantini $C$, et al. Rivaroxaban as an effective alternative to warfarin in a patient with atrial fibrillation, thrombophilia, and left atrial appendage thrombus: a case report. J Med Case Rep 2017;11:97.

23. Casale M, Quattrocchi S, Bitto R, Dattilo G. Cardiac implantable devices and takotsubo syndrome. A rare but potential eventuality. Cor Vasa 2018;60:e500-e502.

24. Dattilo G, Falanga G, Casale M, et al. Oral anticoagulants: old and new therapy. In: Berhardt LV (Ed.). Advances in Medicine and Biology. New York: Nova Science Publishers, 2015:13-71. 